\title{
Serinicoccus chungangensis sp. nov., isolated from tidal flat sediment, and emended description of the genus Serinicoccus
}

Correspondence

Wonyong Kim

kimwy@cau.ac.kr

\author{
Jitsopin Traiwan, Mi-Hak Park and Wonyong Kim
}

Department of Microbiology and Research Institute for Translational System Biomics, Chung-Ang University College of Medicine, 221 Heukseok-dong, Dongjak-gu, Seoul 156-756, Republic of Korea

\begin{abstract}
A Gram-positive, halophilic bacterium, strain CAU $9536^{\top}$, was isolated from a tidal flat sediment in the Yellow Sea, Republic of Korea. Strain CAU $9536^{\top}$ grew optimally at $30{ }^{\circ} \mathrm{C}$, at $\mathrm{pH} 9.0$ and in the presence of $13.0 \%(\mathrm{w} / \mathrm{v}) \mathrm{NaCl}$. Phylogenetic analysis based on 16S rRNA gene sequences revealed that strain $\mathrm{CAU} 9536^{\top}$ belonged to the genus Serinicoccus, and showed sequence similarity levels of $99.0 \%$ to Serinicoccus profundi MCCC 1 A05965 ${ }^{\top}$ and $98.0 \%$ to Serinicoccus marinus $\mathrm{JC} 1078^{\top}$. DNA-DNA relatedness values between strain CAU $9536^{\top}$ and the above two type strains were below $45.0 \%$. The cell-wall peptidoglycan of strain CAU $9536^{\top}$ was based on meso-diaminopimelic acid, in contrast to those of $S$. profundi and $S$. marinus. The polar lipids were diphosphatidylglycerol, phosphatidylglycerol, phosphatidylcholine and phosphatidylinositol. Whole-cell hydrolysates contained mainly glucose and ribose. The major isoprenoid quinone was menaquinone MK-8 $\left(\mathrm{H}_{4}\right)$, and the predominant cellular fatty acid was iso- $C_{15}$ : 0 . The DNA G $+C$ content of strain $C A U 9536^{\top}$ was $73.5 \mathrm{~mol} \%$. Based on phenotypic, chemotaxonomic and genotypic data, strain CAU $9536^{\top}$ is considered to represent a novel species of the genus Serinicoccus, for which the name Serinicoccus chungangensis sp. nov. is proposed. The type strain is CAU $9536^{\top}$ (=KCTC $19774^{\top}=$ CCUG $59777^{\top}$ ).
\end{abstract}

The genus Serinicoccus was described by Yi et al. (2004) and belongs to the family Intrasporangiaceae. At the time of writing, the genus comprised two recognized species, Serinicoccus marinus, isolated from seawater (Yi et al., 2004), and Serinicoccus profundi, isolated from deep-sea sediment (Xiao et al., 2011). Members of the genus are moderately halophilic, Gram-positive cocci, and contain $\mathrm{L}$-ornithine and $\mathrm{L}$-serine as the diagnostic diamino acids in the cell-wall peptidoglycan (Yi et al., 2004). The purpose of this study was to establish the taxonomic position of strain CAU $9536^{\mathrm{T}}$, isolated from a tidal flat sediment sample collected from Seogmo Island in the Yellow Sea $\left(12^{\circ} 55.24^{\prime} \mathrm{S} 76^{\circ} 09.03^{\prime} \mathrm{E}\right)$, Republic of Korea.

Strain CAU $9536^{\mathrm{T}}$ was isolated by the dilution-plate technique on glucose-yeast extract agar (GYEA; per litre: $10 \mathrm{~g}$ yeast extract, $10 \mathrm{~g}$ glucose and $15 \mathrm{~g}$ agar) (Gordon \& Mihm, 1962), supplemented with cycloheximide (50 $\left.\mathrm{mg} \mathrm{l}^{-1}\right)$ and nalidixic acid $\left(20 \mathrm{mg} \mathrm{l}^{-1}\right)$ for industrial screening of micro-organisms. Samples were diluted with sterilized distilled water, and serial dilutions were spread onto GYEA

The GenBank/EMBL/DDBJ accession number for the 16S rRNA gene sequence of strain CAU $9536^{\top}$ is HM068886.

Three supplementary figures and a supplementary table are available with the online version of this paper. and incubated under aerobic conditions at $30{ }^{\circ} \mathrm{C}$ for 3 days. Strain CAU $9536^{\mathrm{T}}$ was stored at $-70{ }^{\circ} \mathrm{C}$ in GYE broth supplemented with $25 \%(\mathrm{v} / \mathrm{v})$ glycerol. Cell morphology was examined by scanning electron microscopy (JSM-5410LV; JEOL).

Growth at $4,10,20,30,37,40$ and $45{ }^{\circ} \mathrm{C}$ was determined on brain heart infusion agar (BHIA; Difco) in an aerobic incubator (model MIR-253; Sanyo) or anaerobic chamber (model Bactron; Sheldon). The $\mathrm{pH}$ range for growth (between $\mathrm{pH} 5.0$ and 11.0 at intervals of $0.5 \mathrm{pH}$ units) and $\mathrm{NaCl}$ tolerance (between 0 and $15 \%$ at intervals of $1 \%$, $\mathrm{w} / \mathrm{v}$ ) were investigated in brain heart infusion broth (BHIB; Difco) at $30{ }^{\circ} \mathrm{C}$ for 3 days. A nutrient sporulation medium was used to produce spores (Nicholson \& Setlow, 1990). After 3 days growth at $30{ }^{\circ} \mathrm{C}$, endospores were examined by using malachite green staining (Smibert \& Krieg, 1994). Catalase activity was determined by bubble production in a $3 \%(\mathrm{v} / \mathrm{v})$ hydrogen peroxide solution. Oxidase activity was determined based on the oxidation of $1 \%(\mathrm{w} / \mathrm{v})$ tetramethyl-p-phenylenediamine (Merck). Enzyme activity was determined with the API ZYM system (bioMérieux), and acid production from glucose and other physiological and biochemical tests were performed with the API 20NE system (bioMérieux), according to the manufacturer's instructions. 
Cellular fatty acid methyl esters were extracted after incubation for 3 days in trypticase soy broth (Difco) at $30{ }^{\circ} \mathrm{C}$ by acid methanolysis (Minnikin et al., 1980) and were analysed by using an Agilent Technologies $56890 \mathrm{~N}$ gas chromatograph (Microbial Identification System Instrument) equipped with a cross-linked $5 \%$ phenyl methyl silicon-fused silica capillary column (HP 19091B-102). Menaquinones were analysed as described by Komagata \& Suzuki (1987) by using reversed-phase HPLC. Extracted polar lipids were identified by using two-dimensional TLC according to the method of Minnikin et al. (1984). Peptidoglycan analysis was performed in our laboratory and by the identification service at the Deutsche Sammlung von Mikroorganismen und Zellkulturen (Braunschweig, Germany) as described by Schleifer (1985), with the modification that TLC was used instead of paper chromatography. Whole-cell sugars were analysed by TLC according to the method of Komagata \& Suzuki (1987).

Genomic DNA of strain CAU $9536^{\mathrm{T}}$ was extracted according to the method of Marmur (1961). The 16S rRNA gene was amplified by PCR following established procedures (Cho et al., 2008), and the amplified DNA was sequenced directly by using BigDye Terminator Cycle Sequencing kits (Applied Biosystems) and an automatic DNA sequencer (model 3730; Applied Biosystems). 16S rRNA gene sequences were analysed by using CLUSTAL_X (Thompson et al., 1997) and the EzTaxon server (Chun et al., 2007). Evolutionary distance matrices were generated by using the method described by Jukes \& Cantor (1969). A phylogenetic tree was constructed via the neighbourjoining (Saitou \& Nei, 1987), least-squares (Fitch \& Margoliash, 1967) and maximum-likelihood (Felsenstein, 1981) methods from the PHYLIP suite of programs (Felsenstein, 1989). The tree topology was evaluated with the bootstrap resampling method with 1000 replicates (Felsenstein, 1985) of the neighbour-joining dataset with the SEQBOOT and CONSENSE programs from the PHYLIP package. The level of DNA-DNA relatedness between strain CAU $9536^{\mathrm{T}}$ and the type strains of the two recognized species of the genus Serinicoccus was estimated by using the fluorometric microplate method (Ezaki et al., 1989), as modified by Goris et al. (1998). The G+C content of the genomic DNA of strain CAU $9536^{\mathrm{T}}$ was determined by HPLC according to the method of Tamaoka \& Komagata (1984), with the modification that the DNA was hydrolysed and the resultant nucleotides were analysed by using reversed-phase HPLC.

Cells of strain CAU $9536^{\mathrm{T}}$ were Gram-positive, nonsporulating, non-motile, strictly aerobic cocci (see Supplementary Fig. S1 in IJSEM Online). Colonies were yellow with convex and entire margins. Growth was observed on BHIA at $20-40{ }^{\circ} \mathrm{C}$, with optimal growth at $30{ }^{\circ} \mathrm{C}$. The optimum $\mathrm{pH}$ for growth was determined in BHIB in a range from $\mathrm{pH} 5.0$ to 11.0, with optimal growth at $\mathrm{pH} 9.0$. Strain CAU $9536^{\mathrm{T}}$ grew in the presence of $0-15 \%(\mathrm{w} / \mathrm{v})$ $\mathrm{NaCl}$, with optimal growth on media containing $13 \%$ $(w / v) \mathrm{NaCl}$.
The phenotypic properties of strain CAU $9536^{\mathrm{T}}$ are listed in Table 1. The strain was catalase-positive but oxidasenegative; it was positive in tests for nitrate reduction, aesculin hydrolysis, and ferric citrate and capric acid assimilation, but negative in tests for indole production. Acid was not generated from D-glucose. Strain CAU $9536^{\mathrm{T}}$ gave a negative result in tests for arginine dihydrolase, urease, gelatin hydrolysis and $\beta$-galactosidase. It was negative for assimilation of D-glucose, L-arabinose, D-mannose, D-mannitol, $\mathrm{N}$-acetylglucosamine, maltose, potassium gluconate, adipic acid, malic acid, trisodium citrate and phenylacetic acid. Positive enzyme activities were obtained for alkaline phosphatase, esterase (C4), esterase lipase (C8), leucine arylamidase, valine arylamidase, cystine arylamidase, trypsin, $\alpha$-chymotrypsin, acid phosphatase, naphthol-AS-BIphosphohydrolase, $\alpha$-galactosidase and $\beta$-glucosidase, but not for lipase (C14), $\beta$-glucuronidase, $\alpha$-glucosidase, $N$ acetyl- $\beta$-glucosaminidase, $\alpha$-mannosidase or $\alpha$-fucosidase.

The cellular fatty acid profile of strain CAU $9536^{\mathrm{T}}$ grown on trypticase soy agar comprised $\mathrm{C}_{15: 0}(4.1 \%$ of the total), $\mathrm{C}_{16: 0}(1.2 \%), \mathrm{C}_{17: 0}(2.6 \%)$, iso- $\mathrm{C}_{14: 0}(2.3 \%)$, iso- $\mathrm{C}_{15: 0}$ $(28.3 \%)$, iso- $\mathrm{C}_{16: 0}(16.8 \%)$, iso- $\mathrm{C}_{17: 0}(2.8 \%)$, iso$\mathrm{C}_{17: 1} \omega 9 c(2.7 \%)$, anteiso- $\mathrm{C}_{15: 0}(19.9 \%)$, anteiso- $\mathrm{C}_{17: 0}$ $(8.0 \%), \mathrm{C}_{17: 1} \omega 6 c(1.8 \%), \mathrm{C}_{17: 1} \omega 8 c(3.4 \%)$ and $\mathrm{C}_{17: 1}$ $3-\mathrm{OH}(1.1 \%)$ (see Supplementary Table S1). Whole-cell

Table 1. Differential phenotypic properties between strain CAU $9536^{\top}$ and its closest phylogenetic relatives

Strains: 1, CAU 9536 $6^{\mathrm{T}}$ 2, Serinicoccus profundi DSM $21363^{\mathrm{T}}$; 3, Serinicoccus marinus KCTC $9980^{\mathrm{T}} ; 4$, Ornithinimicrobium humiphilum DSM $12362^{\mathrm{T}} ; 5$, Ornithinimicrobium kibberense DSM $17687^{\mathrm{T}}$; 6, Kytococcus sedentarius DSM 20547 ${ }^{\mathrm{T}}$. +, Positive; -, negative; $\mathrm{W}$, weakly positive. All data are from the present study.

\begin{tabular}{|c|c|c|c|c|c|c|}
\hline Characteristic & 1 & 2 & 3 & 4 & 5 & 6 \\
\hline Nitrate reduction & + & + & - & + & + & - \\
\hline Growth with $7 \%(w / v) ~ \mathrm{NaCl}$ & + & + & + & - & + & + \\
\hline Growth at $45^{\circ} \mathrm{C}$ & - & - & - & + & - & - \\
\hline Growth at $\mathrm{pH} 9.0$ & + & + & - & - & + & - \\
\hline Hydrolysis of aesculin & + & + & $\mathrm{w}$ & $\mathrm{W}$ & $\mathrm{W}$ & $\mathrm{W}$ \\
\hline \multicolumn{7}{|l|}{ Enzyme activity: } \\
\hline Acid phosphatase & + & - & - & - & - & $\mathrm{w}$ \\
\hline Alkaline phosphatase & + & + & - & - & - & $\mathrm{W}$ \\
\hline$\alpha$-Chymotrypsin & + & + & - & $\mathrm{W}$ & - & - \\
\hline Cystine arylamidase & $\mathrm{w}$ & + & - & $\mathrm{W}$ & $\mathrm{W}$ & - \\
\hline Esterase (C4) & + & + & + & + & $\mathrm{w}$ & + \\
\hline Esterase lipase (C8) & + & + & - & $\mathrm{W}$ & - & - \\
\hline$\alpha$-Galactosidase & $\mathrm{w}$ & - & - & - & - & - \\
\hline$\beta$-Glucosidase & $\mathrm{W}$ & + & - & - & - & - \\
\hline Leucine arylamidase & + & + & - & + & - & $\mathrm{W}$ \\
\hline $\begin{array}{l}\text { Naphthol-AS-BI- } \\
\text { phosphohydrolase }\end{array}$ & $\mathrm{W}$ & - & $\mathrm{W}$ & $\mathrm{W}$ & $\mathrm{W}$ & $\mathrm{W}$ \\
\hline Trypsin & $\mathrm{W}$ & + & - & + & - & - \\
\hline Valine arylamidase & + & + & + & $\mathrm{W}$ & - & - \\
\hline DNA G $+C$ content $(\mathrm{mol} \%)$ & 73.5 & 72 & 72 & 70 & 71 & 69 \\
\hline
\end{tabular}


hydrolysates contained mainly glucose and ribose. The predominant isoprenoid quinone was menaquinone MK8 $\left(\mathrm{H}_{4}\right)$. Strain CAU $9536^{\mathrm{T}}$ had a cell-wall peptidoglycan based on meso-diaminopimelic acid as the diagnostic diamino acid (see Supplementary Fig. S2), in contrast to $S$. marinus and $S$. profundi, which have a cell-wall peptidoglycan based on L-ornithine, glutamic acid, alanine, glycine and serine (Yi et al., 2004). The occurrence of mesodiaminopimelic acid has only been reported for peptidoglycan type $A 1 \gamma$ and for three variations of peptidoglycan type $\mathrm{A} 4 \gamma$ (A31.1, A31.2 and A31.3, see http://www.dsmz. de/microorganisms/main.php?content_id=35). Strain CAU $9536^{\mathrm{T}}$ had peptidoglycan type $\mathrm{A} 1 \gamma$ (A31 according to http://www.dsmz.de/microorganisms/main.php?content $\mathrm{id}=35)$. The polar lipids were diphosphatidylglycerol, phosphatidylglycerol, phosphatidylcholine, phosphatidylinositol and an unknown lipid (see Supplementary Fig. S3), a slightly different profile from those of $S$. marinus $\mathrm{JC} 1078^{\mathrm{T}}$ and S. profundi MCCC $1 \mathrm{~A} 05965^{\mathrm{T}}$.

A nearly complete $16 \mathrm{~S}$ rRNA gene sequence (1511 bp) of strain CAU $9536^{\mathrm{T}}$ was obtained and compared with the corresponding sequences from other bacterial strains in the GenBank database. Phylogenetic analysis indicated that strain CAU $9536^{\mathrm{T}}$ belonged to the genus Serinicoccus (Fig. 1), and was related most closely to S. profundi MCCC

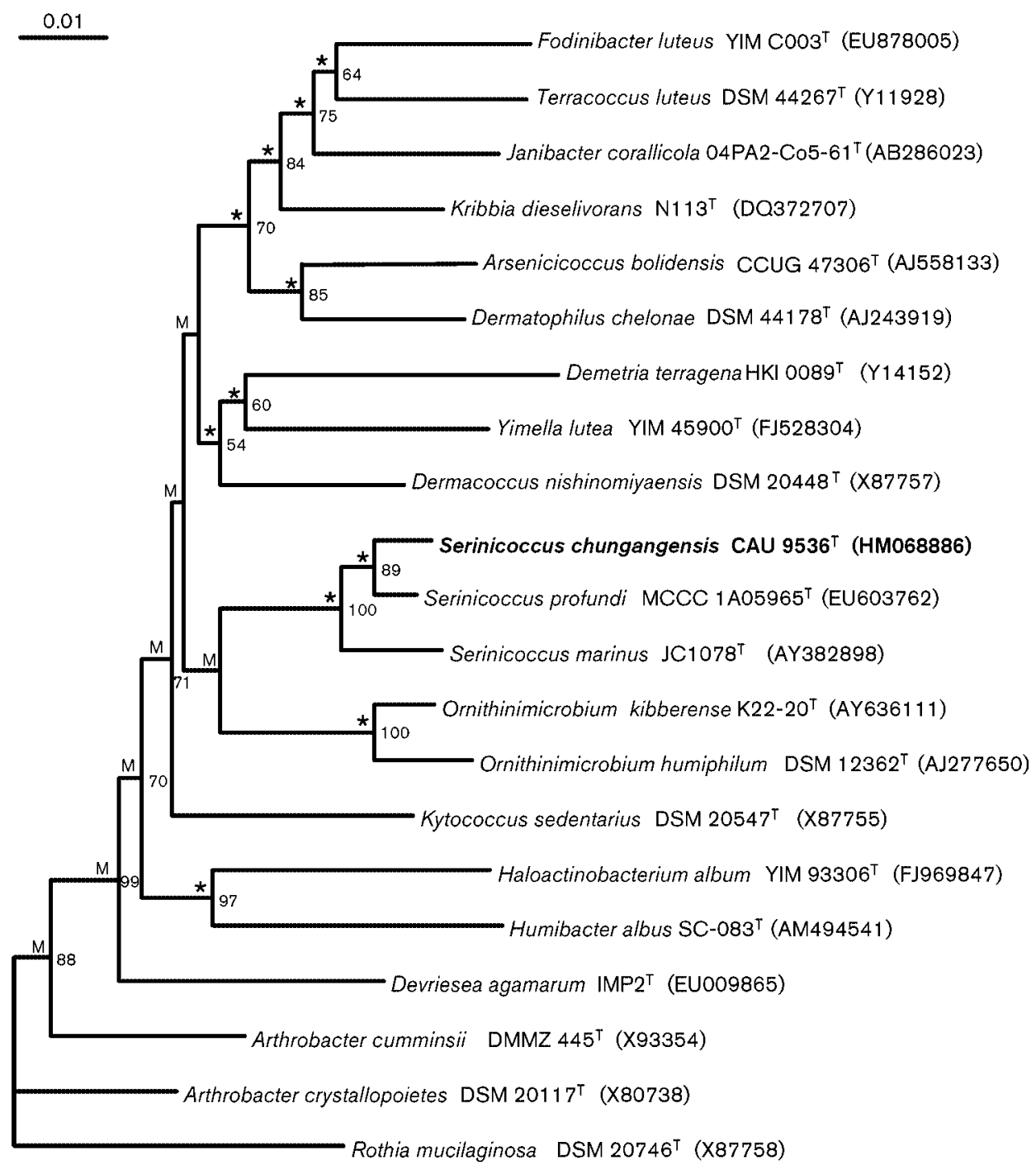

Fig. 1. Neighbour-joining phylogenetic tree based on nearly complete $16 \mathrm{~S}$ rRNA gene sequences (1511 nt), showing the relationships between strain CAU $9536^{\top}$ and the type strains of closely related species. Branches of the tree that were also found by using the least-squares and maximum-likelihood algorithms are indicated by asterisks. Branches also obtained by using the maximum-likelihood method are indicated by the letter M. Numbers at nodes indicate levels of bootstrap support based on a neighbour-joining analysis of 1000 resampled datasets; only values $>50 \%$ are given. Bar, 0.01 substitutions per nucleotide position. 
$1 \mathrm{~A} 05965^{\mathrm{T}}$ (99.0\% $16 \mathrm{~S}$ rRNA gene sequence similarity), $S$. marinus $\mathrm{JC} 078^{\mathrm{T}}$ (98.0\%), Ornithinimicrobium kibberense $\mathrm{K} 22-20^{\mathrm{T}}(95.0 \%)$, Kytococcus sedentarius DSM $20547^{\mathrm{T}}$ $(94.7 \%)$ and Ornithinimicrobium humiphilum DSM $12362^{\mathrm{T}}$ (94.6\%). Levels of DNA-DNA relatedness between strain CAU $9536^{\mathrm{T}}$ and S. profundi MCCC $1 \mathrm{~A} 05965^{\mathrm{T}}$ and S. marinus $\mathrm{JC} 1078^{\mathrm{T}}$ were $40.2 \pm 1.2$ and $44.1 \pm 2.1 \%$, respectively (mean \pm SD of 5 determinations). These values are below the $70 \%$ cut-off recommended by Wayne et al. (1987) for the delineation of genomic species, supporting the classification of strain CAU $9536^{\mathrm{T}}$ as representing a separate species. The DNA G + C content of strain CAU $9536^{\mathrm{T}}$ was $73.5 \mathrm{~mol} \%$.

These data, together with the phenotypic and chemotaxonomic data for strain CAU 9536 ${ }^{\mathrm{T}}$, provide sufficient evidence to support the proposal that this strain represents a novel species of the genus Serinicoccus, for which the name Serinicoccus chungangensis sp. nov. is proposed.

\section{Description of Serinicoccus chungangensis sp. nov.}

Serinicoccus chungangensis (chung.ang.en'sis. N.L. masc. adj. chungangensis of or belonging to Chung-Ang University, where the taxonomic studies on this species were performed).

Cells are Gram-positive, moderately halophilic, nonsporulating, strictly aerobic, non-motile cocci. Colonies are yellow with convex and entire margins. Growth occurs at $20-40{ }^{\circ} \mathrm{C}$ (optimum $30{ }^{\circ} \mathrm{C}$ ), at $\mathrm{pH} 5.0-11.0$ (optimum $\mathrm{pH} 9.0)$ and in the presence of $0-15 \%(\mathrm{w} / \mathrm{v}) \mathrm{NaCl}$ (optimum 13\%). Positive in tests for catalase, nitrate reduction, aesculin hydrolysis and assmilation of ferric citrate and capric acid. Positive in tests for enzyme activities of alkaline phosphatase, esterase (C4), esterase lipase (C8), leucine arylamidase, valine arylamidase, cystine arylamidase, trypsin, $\alpha$-chymotrypsin, acid phosphatase, naphthol-AS-BI-phosphohydrolase, $\alpha$-galactosidase and $\beta$-glucosidase. The cell-wall peptidoglycan contains mesodiaminopimelic acid as the diagnostic diamino acid. The major isoprenoid quinone is menaquinone MK8 $\left(\mathrm{H}_{4}\right)$. Whole-cell hydrolysates contain mainly glucose and ribose. The polar lipids are diphosphatidylglycerol, phosphatidylglycerol, phosphatidylcholine, phosphatidylinositol and an unknown lipid. The predominant cellular fatty acids are $\mathrm{C}_{15: 0}, \mathrm{C}_{16: 0}, \mathrm{C}_{17: 0}$, iso- $\mathrm{C}_{14: 0}$, iso- $\mathrm{C}_{15: 0}$, iso- $\mathrm{C}_{16: 0}$, iso- $\mathrm{C}_{17: 0}$, iso- $\mathrm{C}_{17: 1} \omega 9 c$, anteiso- $\mathrm{C}_{15: 0}$, anteiso- $\mathrm{C}_{17: 0}$, $\mathrm{C}_{17: 1} \omega 6 c, \mathrm{C}_{17: 1} \omega 8 c$ and $\mathrm{C}_{17: 1} 3-\mathrm{OH}$.

The type strain, CAU $9536^{\mathrm{T}}\left(=\mathrm{KCTC} 19774^{\mathrm{T}}=\mathrm{CCUG}\right.$ $59777^{\mathrm{T}}$ ), was isolated from a tidal flat sediment sample collected from Seogmo Island in the Yellow Sea, Republic of Korea. The DNA G $+\mathrm{C}$ content of the type strain is $73.5 \mathrm{~mol} \%$.

\section{Emended description of the genus Serinicoccus Yi et al. 2004}

The description of the genus Serinicoccus is as given by Yi et al. (2004) and Xiao et al. (2011) with the following amendments. The cell-wall peptidoglycan is based on L-ornithine, glutamic acid, alanine, glycine and serine or meso-diaminopimelic acid. The polar lipids are diphosphatidylglycerol, phosphatidylglycerol and phosphatidylinositol. Phosphatidylcholine may be present. The G+C content of the DNA is in the range $72-73.5 \mathrm{~mol} \%$.

\section{Acknowledgements}

This work was supported by the 21C Frontier Microbial Genomics and Applications Center Program, Ministry of Education, Science \& Technology, Republic of Korea (grant 11-2008-03-002-00).

\section{References}

Cho, S. L., Nam, S. W., Yoon, J. H., Lee, J. S., Sukhoom, A. \& Kim, W. (2008). Lactococcus chungangensis sp. nov., a lactic acid bacterium isolated from activated sludge foam. Int J Syst Evol Microbiol 58, 1844-1849.

Chun, J., Lee, J. H., Jung, Y., Kim, M., Kim, S., Kim, B. K. \& Lim, Y. W. (2007). EzTaxon: a web-based tool for the identification of prokaryotes based on $16 \mathrm{~S}$ ribosomal RNA gene sequences. Int J Syst Evol Microbiol 57, 2259-2261.

Ezaki, T., Hashimoto, Y. \& Yabuuchi, E. (1989). Fluorometric deoxyribonucleic acid-deoxyribonucleic acid hybridization in microdilution wells as an alternative to membrane filter hybridization in which radioisotopes are used to determine genetic relatedness among bacterial strains. Int J Syst Bacteriol 39, 224-229.

Felsenstein, J. (1981). Evolutionary trees from DNA sequences: a maximum likelihood approach. J Mol Evol 17, 368-376.

Felsenstein, J. (1985). Confidence limits on phylogenies: an approach using the bootstrap. Evolution 39, 783-791.

Felsenstein, J. (1989). PHYLIP - phylogeny inference package (version 3.2). Cladistics 5, 164-166.

Fitch, W. M. \& Margoliash, E. (1967). Construction of phylogenetic trees. Science 155, 279-284.

Gordon, R. E. \& Mihm, J. M. (1962). Identification of Nocardia caviae (Erikson) nov. comb. Ann N Y Acad Sci 98, 628-636.

Goris, J., Suzuki, K., De Vos, P., Nakase, T. \& Kersters, K. (1998). Evaluation of a microplate DNA-DNA hybridization method compared with the initial renaturation method. Can J Microbiol 44, 1148-1153.

Jukes, T. H. \& Cantor, C. R. (1969). Evolution of protein molecules. In Mammalian Protein Metabolism, vol. 3, pp. 21-132. Edited by $\mathrm{H}$. N. Munro. New York: Academic Press.

Komagata, K. \& Suzuki, K. (1987). Lipid and cell-wall analysis in bacterial systematics. Methods Microbiol 19, 161-207.

Marmur, J. (1961). A procedure for the isolation of deoxyribonucleic acid from microorganisms. J Mol Biol 3, 208-218.

Minnikin, D. E., Hutchinson, I. G., Caldicott, A. B. \& Goodfellow, M. (1980). Thin-layer chromatography of methanolysates of mycolic acid-containing bacteria. J Chromatogr A 188, 221-233.

Minnikin, D. E., O'Donnell, A. G., Goodfellow, M., Alderson, G., Athalye, M., Schaal, K. P. \& Parlett, J. H. (1984). An integrated procedure for the extraction of bacterial isoprenoid quinones and polar lipids. J Microbiol Methods 2, 233-241.

Nicholson, W. L. \& Setlow, P. (1990). Sporulation, germination, and outgrowth. In Molecular Biological Methods for Bacillus, pp. 391-450. Edited by C. R. Harwood \& S. M. Cutting. Chichester: Wiley. 
Saitou, N. \& Nei, M. (1987). The neighbor-joining method: a new method for reconstructing phylogenetic trees. Mol Biol Evol 4, 406425.

Schleifer, K. H. (1985). Analysis of the chemical composition and primary structure of murein. Methods Microbiol 18, 123-156.

Smibert, R. M. \& Krieg, N. R. (1994). Phenotypic characterization. In Methods for General and Molecular Bacteriology, pp. 607-654. Edited by P. Gerhardt, R. G. E. Murray, W. A. Wood \& N. R. Krieg. Washington, DC: American Society for Microbiology.

Tamaoka, J. \& Komagata, K. (1984). Determination of DNA base composition by reverse-phase high-performance liquid chromatography. FEMS Microbiol Lett 25, 125-128.

Thompson, J. D., Gibson, T. J., Plewniak, F., Jeanmougin, F. \& Higgins, D. G. (1997). The CLUSTAL_X windows interface: flexible strategies for multiple sequence alignment aided by quality analysis tools. Nucleic Acids Res 25, 4876-4882.

Wayne, L. G., Brenner, D. J., Colwell, R. R., Grimont, P. A. D., Kandler, O., Krichevsky, M. I., Moore, L. H., Moore, W. E. C., Murray, R. G. E. \& other authors (1987). International Committee on Systematic Bacteriology. Report of the ad hoc committee on reconciliation of approaches to bacterial systematics. Int J Syst Bacteriol 37, 463-464.

Xiao, J., Luo, Y., Xie, S. \& Xu, J. (2011). Serinicoccus profundi sp. nov., an actinomycete isolated from deep-sea sediment, and emended description of the genus Serinicoccus. Int J Syst Evol Microbiol 61, 1619.

Yi, H., Schumann, P., Sohn, K. \& Chun, J. (2004). Serinicoccus marinus gen. nov., sp. nov., a novel actinomycete with L-ornithine and L-serine in the peptidoglycan. Int J Syst Evol Microbiol 54, 1585-1589. 